\title{
A motivação para a leitura na escola: contribuições do ensino de literatura
}

\author{
The motivation for reading in school: contributions of literature teaching
}

\author{
André Luis Machado Galvão* \\ Universidade do Minho \\ Braga, Portugal \\ António Carvalho da Silva** \\ Universidade do Minho \\ Braga, Portugal
}

Resumo: Este trabalho discute a importância da leitura para o mundo contemporâneo e como ela tem sido trabalhada na escola, considerando em que termos o ensino de literatura pode ser motivador da formação do gosto pelo ato de ler. A partir de pesquisa bibliográfica, são analisadas concepções e teorias que embasam as considerações que norteiam o estudo. É possível concluir que o ensino de literatura, através do letramento literário, pode se constituir como recurso motivador para que, no ambiente escolar, venha a ocorrer a formação de leitores críticos e autônomos.

Palavras-chave: Leitura. Motivação. Ensino de literatura.

\begin{abstract}
This paper discusses the importance of reading to the contemporary world and how it has been worked in school, considering in what terms the teaching of literature can be motivating the formation of taste by reading. From a bibliographical research, are analyzed conceptions and theories that base the considerations that guide the research. It is possible to conclude that literature teaching, through literary literacy, can be a motivating resource for the formation of critical and autonomous readers in the school environment.
\end{abstract}

Keywords: Reading. Motivation. Literature teaching.

\section{INTRODUÇÃO}

O mundo atual se move em torno da leitura. Não apenas dos textos escritos, mas das múltiplas linguagens que se emaranham nesse universo globalizado e globalizante. Ler se torna cada vez mais essencial, uma imposição crescente num contexto em que se exigem do indivíduo múltiplas capacidades e competências. Além da sua importância para o mundo competitivo do trabalho, a leitura traz em si um sopro libertador, capaz de produzir e reproduzir ideias e senso crítico, de ampliar horizontes e de fortalecer convicções, enfim, capaz de direcionar a existência humana a um objetivo que se constrói através dela e pelo qual se luta a vida inteira.

A atividade leitora é comum ao ser humano, mas não se encerra apenas no ato de decodificar palavras, símbolos ou gestos, pois requer interpretação, discernimento, criticidade. No mundo contemporâneo, as armadilhas que se impõem aos que não dominam a leitura são tão perigosas quanto as que são impostas aos que leem mal, sem interpretar, analisar ou contextualizar.

* Doutor em Ciências da Educação pela Universidade do Minho. E-mail: almgalvao@uol.com.br.

** Doutor em Metodologia do Ensino do Português pela Universidade do Minho. Membro do CIED e Professor auxiliar da Universidade do Minho. E-mail: acsilva@ie.uminho.pt. 
Portanto, ler não deve ser um ato mecânico de decifração de caracteres, mas sim uma atividade complexa e poderosa através da qual o indivíduo desenvolve suas ideias e opiniões, marcando o seu lugar na sociedade na qual se insere.

Diante disso e considerando a relevância da escola como espaço em que o indivíduo naturalmente aprende e/ou desenvolve a prática da leitura, o ensino de literatura, através do advento do letramento literário e o que ele representa em torno da leitura por prazer e de forma autônoma, pode ser um elemento motivador para que os estudantes se interessem pelo ato de ler, a partir do contato com textos literários diversificados. Nesse contexto, partindo da ideia de que a motivação em sala de aula se propõe, com base em determinadas práticas, a direcionar os estudantes a atividades definidas em prol de um objetivo, ela pode ser usada como estratégia para estimular nos discentes a formação do gosto pela leitura a partir de práticas pedagógicas, e mais especificamente aquelas relacionadas com o ensino de literatura. Assim, através da ação docente, nas aulas de literatura, deve buscar-se a contemplação da realidade escolar e dos estudantes para que se sintam motivados, considerando todo o contexto como um conjunto cujas características atuem simultaneamente nesse processo.

\section{ALGUMAS NOÇÕES SOBRE LEITURA}

A leitura, para Martins (2010), configura-se como um procedimento de compreensão de expressões formais ou simbólicas, relacionando-se não exclusivamente aos códigos escritos, mas a outras expressões humanas, e estabelece uma relação histórica entre o leitor e aquilo que é lido. Nessa concepção, o ato de ler extrapola o texto e se inicia antes mesmo do contato com ele, assumindo o leitor uma postura ativa, negando a posição de simples decodificador ou receptor passivo da sua mensagem. A autora enuncia que a leitura acontece a partir do diálogo entre o leitor e o objeto que ele lê, não importando a sua forma: escrito, sonoro, factual etc. Esse diálogo, por sua vez, é referenciado por um tempo e um espaço, sendo operacionalizado conforme "[...] os desafios e as respostas que o objeto apresenta, em função de expectativas e necessidades, do prazer das descobertas e do reconhecimento de vivências do leitor" (MARTINS, 2010, p. 33).

Segundo Costa (2012), a leitura é um ato de inteligência que pressupõe a execução de procedimentos diversificados, em que, além de absorver o conteúdo dos textos, é possível atribuirlhes sentido. Kleiman (2008, p. 49) igualmente compreende a leitura como uma atividade diretamente ligada ao âmbito dos significados, ao afirmar que "[...] a leitura é um ato individual de construção de significados num contexto que se configura mediante a interação entre autor e leitor, e que, portanto, será diferente, para cada leitor, dependendo de seus conhecimentos, interesses e objetivos do momento". Em complementação, Cafiero (2005, p. 17) entende a leitura como "[...] um processo cognitivo de construção de sentidos realizado por sujeitos sociais inseridos num tempo histórico, numa dada cultura". Essa concepção vê a leitura como um processo em que o indivíduo não apenas decodifica sinais, mas acima de tudo produz sentidos a partir das informações fornecidas pelo autor daquilo que lê: "Nesse processo, o leitor busca no texto um ponto de partida, um conjunto de instruções, relaciona essas instruções com as informações que já fazem parte de seu conhecimento, com o que já aprendeu em outras situações, produzindo sentidos ou construindo coerência para o texto". Decorre dessa abordagem que o sentido não é uma atribuição específica de um texto, pois está diretamente relacionado com a ação de quem o processa.

E, no que se refere à compreensão na leitura, Giasson (1993) a concebe como uma atividade complexa, fruto da interação entre três fatores: o texto, o leitor, e o contexto. Assim, trata-se de um processo global, que entrelaça os fatores citados, em que a construção dos sentidos no texto 
não está limitada aos conhecimentos dispostos em sua superfície, pois envolve a participação do leitor, a partir da articulação entre seus conhecimentos e o conteúdo do texto, dentro de um contexto específico. Deduz-se, portanto, que a compreensão na leitura se faz de maneira ativa e interacional.

Diante dessas considerações, coloca-se um dos maiores desafios da humanidade nos dias de hoje: como formar leitores críticos e capazes de explorar com habilidade todas as possibilidades que a atividade leitora pode proporcionar? Essa pergunta oportuniza dois horizontes de resposta, que compreendem a atuação da família e da escola. Para muitos, o indivíduo tem sua aprendizagem leitora no seio do próprio lar, através da orientação e acompanhamento de pais e familiares, trazendo suas próprias experiências e convicções. Nesse sentido, não se pode negar o quão importante é a família como agente formador, uma vez que a proximidade e a intimidade com parentes podem trazer segurança e conforto no processo de aprendizagem da leitura.

Por outro lado, é preciso salientar o papel da escola no desenvolvimento da capacidade de ler, sendo o espaço onde o indivíduo não precisa apenas de decodificar símbolos, mas também usar essa capacidade associada aos múltiplos conhecimentos que ela é capaz de interligar. Além disso, no ambiente educacional, há as leituras inerentes à dinâmica dos currículos e a interação entre pessoas, as diferentes opiniões, o que em conjunto ajuda a solidificar uma prática leitora que precisa de se aperfeiçoar diante das exigências naturais do avanço escolar através dos anos, até à universidade. Berenblum (2009) reconhece, na leitura, duas dimensões, fruitiva e informativa, que julga complementares e decisivas para a formação de um pensamento autônomo no sujeito. Por isso, entende que a atividade leitora deve estar inserida em um grupo de iniciativas não exclusivamente escolarizadas, sendo realizada em diferentes suportes e em vários códigos, pois o acesso de estudantes a práticas socioculturais diversas é indispensável para o seu domínio do universo de linguagens que circulam na sociedade.

\section{A LEITURA E SUA IMPORTÂNCIA SOCIAL}

Nos tempos atuais, em que a aceleração da vida cotidiana deixa pouco espaço para a reflexão e contemplação, em que resta pouco tempo para o ócio ou para uma atividade descompromissada, a leitura pode proporcionar fruição e consequente reflexão num mundo cujo direcionamento se faz pela pressa e pela produção desenfreada. Nesse contexto, Yunes (2003) afirma que

A leitura [...] passou, paradoxalmente, a ser um precioso instrumento de reaproximação à vida, pelo qual o deslocamento de horizonte provocado pelo texto, pela interação que mobiliza o sujeito do desejo, ressitua o leitor e faz com que ele possa atualizar o texto no ângulo da sua historicidade, da sua experiência, dando-lhe também vida nova (YUNES, 2003, p. 11).

Também nessa direção, Azevedo (2013, p. 85) complementa esse ponto de vista, ao afirmar que a leitura serve "[...] para que o indivíduo se conheça a si próprio e adquira uma mais profunda consciência dos seus interesses". O ato de ler, segundo Costa (2012), ainda se reveste de importância diante das exigências cada vez mais diversificadas impostas pelas sociedades contemporâneas, pois propicia ao indivíduo competências e habilidades que podem viabilizar o seu ingresso no mundo do trabalho.

Apesar da importância atribuída a si sob vários aspectos, há referências a uma "crise da leitura", discutida em estudos acadêmicos e no contexto educacional, não só no Brasil. Para essa crise, têm contribuído vários fatores, entre eles os avanços tecnológicos e a difusão de novos 
instrumentos que podem significar o menor interesse pelos livros ou a leitura de textos mais simplificados, como apresentam as redes sociais. Além das inovações da tecnologia, Costa (2012) menciona a "crise" e a relaciona a outros elementos, como os preços dos livros e a falta de sua valorização pela sociedade como um todo. Ainda pertinente a essa questão, Lajolo (2002) determina que a atividade de leitura, outrora individual e reflexiva, converteu-se, na atualidade, numa espécie de "obsolescência programada":

A atividade da leitura, que em suas origens, era individual e reflexiva (em oposição ao caráter coletivo, volátil e irrecuperável da oralidade de poetas e contadores de histórias), transformouse hoje em consumo rápido do texto, em leitura dinâmica que, para ser lucrativa, tem de envelhecer depressa, gerando constantemente a necessidade de novos textos (LAJOLO, 2002, p. 105).

Assim, um dos grandes desafios para incentivar a leitura no mundo contemporâneo é agregar a essa prática a lógica da qualidade. Num contexto onde o consumo exagerado aponta para a supremacia da quantidade sobre a qualidade, não é absurdo pensar que até mesmo o ato de ler esteja sendo considerado sob a lógica do "quanto mais, melhor", deixando de lado aspectos essenciais, como a compreensão, a análise e o debate dos textos lidos.

Nessa conjuntura, a leitura torna-se uma atividade mecânica, crítica, desprovida da profundidade inerente à sua boa execução. Se o indivíduo substitui por completo leituras mais complexas, que estimulam efetivamente a análise crítica da realidade, por leituras mais simples, condizentes com os modismos e exigências mercadológicas, que normalmente apresentam tramas e discussões simplórias, a médio prazo, terá a sua capacidade interpretativa e crítica reduzida, por não estimular essa capacidade com maior frequência em seu processo cognitivo.

Isso, no entanto, não quer dizer necessariamente que toda a obra literária, ficcional ou não, que seja fruto de modismo literário ou de estratégia mercadológica seja simplória em seu conteúdo, mas ocorre que esse tipo de produção está vinculado a modelos que trazem consigo uma indiscutível tendência de previsibilidade. Dessa maneira, o leitor se torna "escravo" de um tipo de história ou teoria, guiado por leituras que não desenvolvem o seu cabedal crítico. Nesse sentido, é importante considerar o que afirma Cosson (2009) sobre o que chama de "literatura de massa", cuja configuração se identifica com as obras acima referidas:

Essas obras são usualmente mais simples do ponto de vista de sua elaboração e consideradas como produto de imposição do mercado e não da criação artística. Tanto é assim que a seleção delas, apesar de percebida pelo leitor como um gesto autônomo, costuma ser denunciada como consequência das restrições a determinados temas, considerados pouco vendáveis ou inadequados para este ou aquele público; dos mecanismos de publicidade que fazem do livro uma mercadoria; e da padronização de gostos e leitores, enfim, promovida pela indústria cultural (COSSON, 2009, p. 39).

Há que se observar, porém, que, diante das sedutoras ferramentas tecnológicas da contemporaneidade, o acesso à leitura precisa ser valorizado, mesmo que sejam leituras de obras mais simples, ou até frutos de modismos, como as coleções de temas que fazem sucesso por temporada. Isso porque essas obras podem se configurar como a "porta de entrada" para uma história de leitura, um incentivo inicial para que a partir daí se descubram novos autores, novas histórias, novas teorias. A experiência leitora precisa ser iniciada do mais simples para o mais complexo para que o leitor vá se formando à medida que elege suas leituras prioritárias conforme suas identificações e gostos, e a partir daí possa ser capaz de descobrir de maneira autônoma 
outras obras e autores que possam despertar-lhe o interesse por novas leituras e também para que possa fazer dela uma atividade fruitiva e proporcionadora da análise da realidade.

É fundamental conceber a leitura como experiência humana diversificada, repleta de significados e de possibilidades, contínua e essencial para a vida em sociedade. O ser humano lê o tempo inteiro, não só os sinais gráficos e suas estruturas mais comuns que se encontram nos textos tradicionais escritos, mas lê também imagens, expressões, contextos. Por isso, o indivíduo precisa desenvolver a criticidade, para que suas leituras possam ser processadas de maneira criteriosa, fazendo com que suas impressões sobre a vida e as pessoas possam conduzir-lhe a uma vida social mais harmônica.

\section{A LEITURA NA ESCOLA}

Concebidas algumas teorias acerca da leitura e da sua importância no mundo contemporâneo, faz-se fundamental discutir como seu ensino é tratado nas escolas, quais as questões que se levantam sobre o papel do professor, as estratégias de trabalho sobre leitura em sala de aula, a seleção dos textos, o uso do livro didático, entre outros. Tais questões são muito relevantes, a fim de analisar o contexto do ensino de leitura, suas dificuldades e perspectivas.

No sentido de delimitar o estudo acerca da leitura no espaço escolar, considerar-se-ão aqui quatro marcos de análise e discussão, componentes do processo que engloba o ensino e aprendizagem de leitura na escola: a escola, o professor, o uso dos textos / livros didáticos e o aluno. Cada um desses elementos integrará um tópico de análise a seguir.

\subsection{A ESCOLA}

O ensino de leitura se inicia no seio familiar, com as primeiras noções de linguagem, através do acompanhamento dos familiares e até mesmo pelo seu exemplo como leitores. Mas é na escola que o indivíduo tem contato mais direto e contínuo com procedimentos sistematizados de ensino da leitura.

$\mathrm{Na}$ escola, desde as séries iniciais até os anos finais da educação básica, em diferentes estágios e modalidades, a leitura é trabalhada como elemento fundante do processo educacional. Nesse contexto, deve considerar-se não apenas a leitura de textos convencionais ou teóricos, mas também de imagens, de símbolos matemáticos, além da interpretação de textos próprios de todas as áreas do conhecimento que fazem parte do currículo escolar:

O papel da escola em relação à leitura alterou-se substancialmente, nos últimos tempos, e ela - a leitura - não pode ser só responsabilidade da aula de Português. Terá que ser uma responsabilidade partilhada para a orientação do gosto e do encantamento pela leitura e pela literatura. Compreender que a leitura é tarefa comum a todas as áreas é o passo inicial para este compromisso (COUTINHO; AZEVEDO, 2007, p. 40).

Assim, a escola, mesmo dentro do seu ordenamento, não se distancia das práticas sociais, constituindo-se o lugar onde predominantemente o indivíduo aprende o ato de ler, sem desconsiderar o contexto social circundante. É sob essa ótica que Dionísio (2000) fala dos elos muito fortes que se mantêm entre leitura e escola. E complementa:

Contexto de leitura, em vários planos e com diversos objectivos, a escola, apesar de especializada pelos objectivos e práticas que promove, estabelece com outros contextos 
relações de interdependência muito fortes. Por um lado, a ela se exigem práticas congruentes com as necessidades sociais, por outro lado, as práticas que aí se promovem dificilmente são destrinçáveis das circunstâncias concretas de seus usos, dentro e fora dela (DIONÍSIO, 2000, p. 40).

Portanto, a escola se apresenta como instituição fundamental para o ensino da leitura, não obstante o fato de que o indivíduo pode ter acesso à leitura através da família ou do autodidatismo. No entanto, no meio escolar, o ensino de leitura vem acompanhado da troca de experiências comum ao conjunto múltiplo de várias personalidades, entre estudantes e professores, e seus diversos pontos de vista. Mas, na escola, também esse ensino está ligado a normas curriculares e imposições de leituras, atreladas a políticas educacionais diversas, correntes teóricas ou exigências de exames avaliativos externos, no caso do Brasil, vestibulares e do ENEM - Exame Nacional do Ensino Médio. Nesse sentido, vale salientar que

$\mathrm{Na}$ medida em que alunos e professores constroem [...] modelos particulares de leitura e entendimentos do que está envolvido na sua aprendizagem, nomeadamente a função social da leitura, a escola pode e deve ser olhada em termos dos contextos de leitura em que introduz os alunos, dos sentidos em que os familiariza, quais ignora, que estilos estimula, que valores, hábitos e atitude promove (DIONÍSIO, 2000, p. 41).

A escola, dessa maneira, entre aspectos positivos e negativos, tem importância fundamental no ensino e aprendizado de leitura e deve ser sempre aperfeiçoada para que possa oferecer o ambiente mais propício para o seu melhor desenvolvimento entre os indivíduos, nos diferentes níveis educacionais.

\subsection{O PROFESSOR}

O professor é peça fundamental no processo de aprendizado da leitura. Através dele, na escola, os estudantes têm acesso a textos cuja interpretação será orientada pelo docente, proporcionando o contato com experiências leitoras que poderão ajudar a formar o gosto dos estudantes pelo ato de ler. O docente, segundo Oliveira (2010), atua como um mediador, como alguém que direciona as leituras, auxiliando no seu processo interpretativo:

A função mediadora que o professor possui no desenvolvimento da competência de leitura dos estudantes é muito importante. Como mediador, cabe ao professor a tarefa de ajudar seus alunos a dominarem estratégias de leitura que lhes sejam úteis nos atos de interpretação textual. Essas estratégias são ações procedimentais estreitamente vinculadas aos conhecimentos prévios dos estudantes, os quais precisam ser abordados em sala de aula (OLIVEIRA, 2010, p. 71).

Uma das maneiras de exercitar essa mediação é através de atividades que ajudem a despertar o interesse pela leitura, explorando os referenciais socioculturais dos alunos e seu conhecimento de mundo. Para Oliveira (2010), é fundamental trabalhar os conhecimentos prévios dos estudantes para alcançar êxito no processo de leitura e interpretação. Ele defende que esses conhecimentos sejam trabalhados em estratégias como a predição - previsão do conteúdo a partir da leitura de elementos textuais, tais como o título, subtítulo ou imagens de um texto; a adivinhação contextual, através da qual o leitor tem acesso aos significados desconhecidos através das pistas que o próprio texto fornece em seu todo; e a identificação das ideias mais importantes, na qual o leitor vai eleger 
em cada parágrafo ou unidade de sentido uma ideia mais importante para o contexto geral do texto.

No entanto, é preciso observar que, na prática, não tem sido comum se levar em conta os referenciais trazidos pelos estudantes. Normalmente, dentro da estrutura escolar, seja por falta de tempo, de interesse ou por uma estrutura pouco organizada e profícua do sistema educacional, o professor deixa de lado esses referenciais e centra a sua prática naquilo que ele conhece e julga eficiente e prático, desprezando a opinião discente na condução do ensino de leitura, seja na escolha dos textos seja na elaboração e execução de atividades inerentes a esse processo.

De acordo com Silva (2005), é de muita importância que o docente conheça e valorize as referências de leitura e de vida de seus estudantes, a fim de se aproximar de suas expectativas e realidades, sendo possível, dessa forma, oferecer-lhes caminhos mais concretos para o ato de ler, levando em consideração seus referenciais. Sob esse mesmo ponto de vista, Martins (2010) defende que a função do professor não é exatamente a de ensinar a ler, mas possibilitar que o estudante efetive sua própria aprendizagem, de acordo com seus interesses e necessidades. Por isso, conforme essa autora, alfabetizar ou proporcionar acesso aos livros não bastam para criar condições de leitura. É necessário o diálogo com o leitor sobre o que lê e sobre os sentidos que ele atribui a isso.

Outro papel fundamental do professor é como exemplo de leitor. Ao visualizarem seu mestre lendo ou quando ele compartilha suas experiências de leitura, os estudantes podem se motivar para o ato de ler, a partir de sua identificação com o exemplo do docente. Terá de haver, portanto, espaço na sala de aula para que docentes e discentes exponham suas experiências leitoras, com o objetivo de fazer circular o conhecimento e as vivências que essas diversas leituras proporcionam. Dessa maneira, abre-se espaço para a percepção de que ler pode ser uma atividade divertida e enriquecedora, e não apenas uma obrigação imposta pelos professores e pelas atividades escolares.

A leitura é concebida por Geraldi (2003) como uma atividade de interlocução entre leitor e autor através da mediação do texto, sendo necessário recuperar nos indivíduos o prazer em realizar $\mathrm{o}$ ato de ler. A leitura fruitiva precisa ser incentivada no contexto escolar, e a participação do professor, a partir da utilização de textos literários, é importante nesse processo. Lajolo (2002), por seu turno, propõe que a prática de leitura promovida pela escola ocorra da forma mais livre possível, o que só acontece quando é respeitado o gosto ou a aversão do leitor em relação a cada livro.

Um desafio muito grande se coloca diante dos professores: mais que ensinar a ler, é preciso ensinar a gostar de ler, considerando todas as variáveis que esse hercúleo trabalho traz em sua configuração. Para além das questões da linguagem, como a aquisição das habilidades de decodificação e interpretação, o docente precisa saber lidar com aspectos mais ligados à subjetividade de cada estudante, como sua compreensão de mundo e suas preferências e interesses. E não é fácil flexibilizar os conteúdos curriculares para ouvir os estudantes e democratizar o processo de ensino e aprendizagem da leitura. Mas fica muito claro que é algo necessário, se o que se quer é um aprendizado efetivo de leitura e a formação de leitores nas escolas.

\subsection{SELEÇÃO DE TEXTOS E USO DO LIVRO DIDÁTICO}

$\mathrm{Na}$ escola, a leitura precisa ser estimulada a partir de dois caminhos: a necessidade dos conteúdos e o gosto dos alunos. Um aspecto não exclui o outro, sendo possível conciliar as exigências inerentes ao processo educacional com estratégias de leitura que levem em 
consideração o gosto do estudante. Para isso, é importante conhecer o universo leitor dos discentes, suas práticas e preferências e, a partir de então, incluir no planejamento das aulas a inserção de textos que mais se aproximem da sua realidade. Tal tarefa requer que o docente seja capaz de compartilhar, mesmo que indiretamente, com o aluno, a seleção de textos a serem trabalhados na escola, algo que não é muito comum de se observar no contexto educacional, como foi dito anteriormente.

Com a adoção de textos mais próximos da realidade leitora dos alunos, espera-se que eles se interessem mais pela leitura, a partir de sua identificação com os textos propostos para estudo. Por outro lado, para o docente, será a oportunidade de ampliar o seu universo de leitura e ter contato com gêneros que normalmente não fazem parte da sua prática leitora. Assim, ele poderá encontrar pontes entre textos mais comumente trabalhados na escola e aqueles que são melhor recebidos pelos estudantes. No entanto, a realidade mais comum no Brasil, na Educação Básica, é que seja proposta aos estudantes a leitura de obras clássicas, principalmente da literatura nacional, dos séculos XIX e início do século XX, segundo Silva (2003). Para ela, essa realidade é uma mostra do processo de adequação da leitura promovido pelos professores, que assim acreditam ser possível assegurar o sucesso do trabalho com a obra estudada e consequentemente a motivação para sua leitura, sem considerar o gosto e as referências dos estudantes.

Esse distanciamento entre a realidade do estudante e a natureza dos textos utilizados na escola contribui para a formação de um público leitor incapaz de ir além do processo de decodificação linguística que caracteriza o estágio inicial da leitura. Sem identificação com os textos que lê, o aluno se distancia de um aprofundamento interpretativo e da capacidade de relacioná-lo com o contexto em que vive, prejudicando inferências e conclusões, tão caras ao processo efetivo da leitura, como destaca Silva (2005), ao discutir o assunto:

A leitura de textos tomados como fins em si mesmos, em função da mistificação daquilo que está escrito, gera uma outra consequência nefasta para a formação do leitor, qual seja, a de estraçalhar a própria natureza do processo de leitura. Se um texto, quando trabalhado, não proporcionar o salto do leitor para o seu contexto (isto é, para a intencionalidade social que determinou o objetivo, o conteúdo e o modo de construção do texto), e mais, se o contexto do texto lido não proporcionar uma compreensão mais profunda do contexto em que o sujeito-leitor se situa ou busca se situar, então a leitura perde a sua validade (SILVA, 2005, p. $4-5)$.

Geraldi (2003), ao tratar do ensino de literatura, menciona a "simulação de leituras": o autor entende que, na escola, ao invés de se lerem efetivamente os textos, são realizados exercícios de interpretação. Também discorre sobre a função da escola no sistema capitalista, ao reproduzir seu ideário, descartando qualquer atividade "não-rendosa": assim, as atividades de leitura têm como objetivo a realização de atividades específicas, como resumos ou fichas de leitura, em detrimento da valorização do seu aspecto fruitivo.

Quanto ao uso do livro didático, a escola é a instância natural dessa utilização, mas esse, na maioria das vezes, limita-se a explorar os textos de maneira fragmentada, sem contextualização com a realidade, sem elementos que conectem o universo textual ao universo social do qual o aluno faz parte. Se, por um lado, esses livros apresentam essa abordagem limitada, por outro, muitas vezes os docentes, adotando-os como único referencial de apoio didático, acabam ratificando essa proposta, repassando para os discentes esse horizonte fragmentado e desconectado dos textos, o que prejudica um aprofundamento da sua análise e também a sua relação com o contexto sociocultural. Essa situação é apontada por Graça (2009), ao afirmar que o texto do manual é o mais utilizado nas aulas de Língua Portuguesa, o que parece provocar alguns 
problemas na formação de leitores, desprezando a livre escolha dos textos por parte dos estudantes. Para essa autora, o excessivo apego ao manual limita o desenvolvimento da mestria dos alunos em literacia de leitura, tendo em vista que essa seleção se baseia em trechos de obras e também em textos antigos, descontextualizados da realidade atual dos discentes. Dessa maneira, a escola transmite aos estudantes a obrigatoriedade de ler uma literatura específica, sem abrir espaço para a discussão de outros caminhos que pudessem refletir de forma mais adequada às demandas dos estudantes e suas expectativas.

Por fim, cabe salientar que tanto a seleção dos textos em sala de aula como a utilização dos livros didáticos precisam ser revistas e democratizadas. Não obstante o fato de serem elementos importantes no processo de ensino e aprendizagem da leitura, seu uso nos termos em que ainda se colocam nos dias de hoje, conforme exposto anteriormente, prejudicam mais que favorecem esse processo.

\subsection{O ALUNO}

Todos os métodos e estratégias para promover a leitura na escola têm como foco o aluno. Não é possível conceber o ato de ler na escola sem colocar o estudante como figura central. Mas se é assim, por que ele tem participado tão pouco desse processo? Ou melhor, tem participado pouco como protagonista, pois o que se vê comumente é a sua participação passiva, como receptor de ideias, procedimentos e atividades, sua opinião ou suas preferências têm sido alijadas do contexto escolar.

Inserir o estudante efetivamente no processo de desenvolvimento da leitura pode garantir o seu aprendizado com qualidade, levando em consideração uma maior capacidade de compreensão e interpretação, não só do texto como do mundo ao seu redor. O mais difícil, nesse aspecto, é como viabilizar que isso ocorra sem que se perca a autonomia docente, sem que as diretrizes curriculares tenham perdas consideráveis ou sem que uns alunos participem mais que outros, impondo suas opiniões.

Essa inserção do discente compreende não só a seleção dos textos, mas a apreensão da realidade de cada indivíduo e suas referências e habilidades, requer a possibilidade de expandir a análise e interpretação textual a um campo propício para o entendimento e reflexão, fazendo com que os estudantes tenham a plena capacidade de ler não apenas como um ato de decodificação de signos, mas como uma atividade plenamente interpretativa, crítica e múltipla em significados. E todas essas ações deveriam encontrar na escola o seu lugar natural de ocorrência, pois

A leitura é uma atividade fundamental para a aprendizagem de qualquer língua. E se o aluno gostar dos textos que lhe são apresentados no manual e nas aulas, se os entender com facilidade, se for capaz de encontrar estratégias que lhe permitam compreendê-los integralmente, então o caminho para que goste das aulas e da própria língua está aberto, mostrando-lhe novos horizontes e levando a que, cada vez mais, sinta prazer na leitura (AMADO; SARDINHA, 2013, p. 53).

No entanto, quando se defende maior participação do estudante no processo de ensino da leitura, não se busca afirmar que ele deverá ter total autonomia ou decidirá exclusivamente as estratégias e caminhos para esse processo. Não, essa função é da escola, como instituição que reúne, sistematiza e executa as regras educacionais vigentes, e do professor, indivíduo possuidor de formação acadêmica, experiência e conhecimento necessários para isso. A participação do discente está relacionada com o fato de ele ser ouvido por esses atores, de suas experiências, 
expectativas e gostos serem levados em conta na construção de um roteiro de ensino que se aproxime mais dessa realidade e que assim possa ter mais chances de êxito.

Enfim, essa participação do estudante pode abrir as portas para que, reconhecendo-se como parte desse processo, tenha mais autonomia e estímulo para desenvolver suas habilidades leitoras, a partir da maior identificação com textos e abordagens sobre estes realizadas no contexto escolar. E, conforme o que aponta Antunes (2013), a leitura se torna plena quando o leitor consegue chegar à compreensão de aspectos ideológicos de um texto, de ideias que normalmente estão dispostas nas entrelinhas. $\mathrm{O}$ ideal, segundo esse ponto de vista, é que o leitor seja capaz de perceber que nenhum texto é dotado de neutralidade, sempre haverá posicionamentos, ideias, visões de mundo, crenças em sua concepção.

\section{CONSIDERAÇÕES SOBRE A MOTIVAÇÃO EM SALA DE AULA}

Motivar os alunos em sala de aula é um constante desafio para os professores em qualquer nível de ensino. Ao desenvolverem suas atividades cotidianas de ensino, suas ações influenciam a motivação e a aprendizagem dos estudantes. E, se o professor quer motivar seus alunos, segundo Tapia (2015), precisa saber de que maneira seus padrões de atuação podem contribuir para proporcionar que os alunos se interessem e se esforcem por aprender e, mais especificamente, que formas de atuação podem auxiliar efetivamente os alunos. Assim, a preocupação em motivar deve ser sempre considerada pelos professores e por toda a comunidade, uma vez que estudantes motivados estão obviamente mais propensos a interagir de forma mais ativa e qualificada no cotidiano de sala de aula, o que certamente proporciona maior eficiência no processo educacional.

A motivação, conforme enunciado por Fita (2015, p. 77), é “[...] um conjunto de variáveis que ativam a conduta e a orientam em determinado sentido para poder alcançar um objetivo". Para esse autor, o estudo da motivação consiste na análise dos fatores que induzem as pessoas a realizar determinadas ações visando seus objetivos. Rosário (2005), por sua vez, reconhece sua importância para a qualidade da aprendizagem e para o nível de rendimento apresentados pelos estudantes durante o processo educacional, uma vez que dirige o seu comportamento, mobilizando seus recursos e atitudes para atingir determinadas finalidades no âmbito dos procedimentos escolares.

Dentre as teorias que se propõem a estudar e explicar a motivação, têm tido maior destaque as abordagens cognitivas, que, segundo Rosário (2005), estudam os processos cognitivos e as variáveis que determinam o comportamento motivado de um indivíduo, estando relacionadas à concepção de que os processos cognitivos fazem a mediação entre o estímulo e a resposta. No campo dessas abordagens, duas modalidades de motivação são mais referidas: motivação extrínseca (relacionada com a obtenção de recompensas externas) e motivação intrínseca (concernente ao interesse do indivíduo pela própria atividade desenvolvida). De acordo com Ribeiro (2011), essas espécies de motivação estão associadas, respectivamente, aos interesses próprios do sujeito e às influências externas recebidas por ele:

$\mathrm{Na}$ motivação extrínseca, o controlo da conduta é decisivamente influenciado pelo meio exterior, não sendo os factores motivacionais inerentes nem ao sujeito nem à tarefa, mas simplesmente o resultado da interacção entre ambos. Na motivação intrínseca, ao contrário, o controlo da conduta depende sobretudo do sujeito em si, dos seus próprios interesses e disposições (RIBEIRO, 2011, p. 2). 
Portanto, em se considerando o ambiente escolar e suas peculiaridades, a motivação extrínseca está ligada às atividades escolares e à necessidade de obtenção de sucesso na sua realização como resposta a pressões ou recompensas externas. Por outro lado, a motivação intrínseca se projeta para a satisfação pessoal do estudante e do desenvolvimento de suas competências e habilidades. Para Neves e Boruchovitch (2004), é uma orientação motivacional que se caracteriza pela ideia de autonomia do estudante e a autorregulação de sua aprendizagem. Ribeiro (2011) defende que a postura relacionada com a motivação intrínseca, a partir do que chama metas de aprendizagem, deve ser incentivada pelos docentes, uma vez que, ao se dedicar para obter maior domínio de conteúdos, independentemente da expectativa em relação ao sucesso obtido na realização de tarefas, o estudante irá investir maior energia em algumas atividades mentais e envolver-se mais facilmente com a própria aprendizagem.

Ademais, no que se refere aos processos motivacionais, a postura do professor na condução de suas aulas também influencia diretamente as práticas dos seus alunos. Portanto, observa-se que "[...] o estilo motivacional do professor é importante fonte de influência para a orientação motivacional dos estudantes, refletindo no seu desempenho escolar" (GUIMARÃES; BORUCHOVITCH, 2004, p. 148). É necessário ter muito cuidado diante dessa situação, uma vez que, muitas vezes, a disposição do aluno para aprender está diretamente relacionada com as decisões e atitudes tomadas pelo profissional docente no curso das aulas.

Mas é preciso vislumbrar um aspecto importante em relação à atuação docente: no contexto educacional brasileiro, há uma série de problemas que ainda comprometem um desenvolvimento mais efetivo do processo educativo e, assim, a própria atuação do professor, como a estrutura precária das escolas, um número considerável de salas de aula superlotadas, a violência e a indisciplina de alguns estudantes, entre outros. Esse quadro, por conseguinte, afeta a sua própria motivação em desenvolver o seu trabalho, o que também se reflete nas práticas motivacionais realizadas em sala de aula: se o professor não se sente motivado, o que pode oferecer como motivação aos seus alunos? Nesse contexto, torna-se muito difícil para o profissional estimular nos discentes o entusiasmo e o interesse pelas atividades escolares.

Logo, pensar a motivação em sala de aula não deve ser compromisso apenas do professor, mas de todos aqueles que estão envolvidos com o contexto escolar: governos, gestores, famílias, alunos, por se configurar um assunto relevante para o aprimoramento das práticas educativas.

\section{O ENSINO DE LITERATURA COMO MOTIVADOR DO GOSTO PELA LEITURA}

Durante muito tempo, aprender a leitura e a escrita foi o principal objetivo do ensino escolar. No mundo contemporâneo, existe a percepção de que essa não pode mais ser a única perspectiva. Em relação à leitura, mais especificamente, cabe à escola formar um leitor crítico, capaz de estabelecer relações e inferências a partir da atividade leitora em conexão com a realidade circundante. Um dos caminhos para que se alcance essa meta é assumir que o estudante desenvolve sua própria leitura dos textos e do mundo e respeitar esses pontos de vista. É inerente à atividade leitora propiciar diversas possibilidades interpretativas a partir do que foi lido, levando em consideração as referências pessoais de cada indivíduo.

A integração dos educandos no universo da leitura por meio da escola está relacionada diretamente com as estratégias de atuação docente, mas não somente com isso. É plausível considerar ainda a relevância dos instrumentos de trabalho (livros e demais materiais didáticos) e de outros recursos auxiliares do processo de ensino-aprendizagem no ambiente escolar (biblioteca, 
recursos multimídia, entre outros). Esse conjunto amplo de fatores, quando inserido de forma articulada nas práticas educativas, influencia de maneira determinante nos resultados alcançados em relação à aprendizagem como um todo e, especificamente, em referência à formação do gosto pela leitura. Recursos diversificados, associados a iniciativas docentes comprometidas com uma educação inovadora, podem representar o desenvolvimento de motivação nos alunos para aprender e descobrir cada vez mais.

A participação do professor é fundamental para que a literatura se transforme num elemento motivador do gosto pela leitura. Para isso, além da realização de atividades democráticas e diferenciadas de leitura e análise de textos literários, o docente motiva seus alunos também pelo seu exemplo de leitor. Um profissional que lê, que fala sobre livros, indica e discute títulos e demonstra entusiasmo em suas leituras estimula os seus discentes a seguir os mesmos caminhos pela lógica do exemplo.

Outrossim, práticas cotidianas e viáveis, como ler textos coletivamente, proporcionar releituras de histórias, promover encontros e conversas com escritores, feiras de livros etc., ajudam a criar a ideia da "comunidade de leitores", um espaço em que a leitura e os livros são assuntos disseminados e valorizados, comuns a todos os membros dessa comunidade. Nesse sentido, conforme Dionísio (2006, p. 53), "A inserção dos sujeitos numa comunidade de leitores passa, entre outras coisas, pela criação de contextos onde a leitura desempenhe funções sociais diversas e valorizadas pelos sujeitos que nela se envolvem". Assim, estando inseridos num contexto onde a leitura é o centro das ações, os educandos tendem a se motivar progressivamente para essa atividade.

Ainda em relação ao professor, Sousa (1998) propõe que o docente ocupe a condição de "respondente/informante", considerando a abordagem escolar do texto centrada na resposta do leitor, tendo como princípio a "[...] consideração do envolvimento produtivo do leitor como condição necessária para a construção dos sentidos textuais e, em consequência, para o prazer na leitura" (SOUSA, 1998, p. 66). Essa condição, ainda conforme a mesma autora, não quer dizer que o professor precise de exercer uma postura passiva, ou seja, aceitar todas as perspectivas desenvolvidas pelo discente. Cabe ao educador a função de estimular a interpretação a partir das respostas dos alunos, orientando-lhes quanto às análises plausíveis e, acima de tudo, ouvindo suas estratégias interpretativas, empenhando-se para entendê-las e desafiá-las. Agindo dessa forma, o docente poderá fazer com que o aluno adquira mais motivação para o ato de ler.

Para ser um recurso motivador para a leitura, o ensino de literatura na escola também precisa reconhecer as experiências literárias dos estudantes e o seu contexto sociocultural, propondo reflexões sobre as práticas de leitura e produção cultural. As múltiplas possibilidades de leitura dos estudantes diante dos mais diversos textos devem ser consideradas, a fim de estimular o gosto pelo ato de ler a partir de textos literários estudados em sala de aula. Assim, é necessário que o ensino de literatura seja um incentivador da leitura, sem impor textos e suas interpretações, que muitas vezes desconsideram as referências culturais dos estudantes ou a sua opinião sobre o que leram e experienciaram.

Nesse contexto, é muito importante que a escola viabilize e desenvolva a proposta do letramento literário como método para a promoção do gosto pela leitura e, consequentemente, para a formação de leitores. Essa proposta, por sua natureza, oferece ao estudante a possibilidade de ter autonomia nas suas escolhas, análises e associações em relação às leituras que realiza. Tratase de um processo que possibilita ao indivíduo ser dotado de uma habilidade que requer constante atualização sobre o universo literário, através do qual ele pode atribuir sentido ao mundo por meio de palavras, transpondo limites de tempo e espaço (COSSON; SOUZA, 2011). Por ser um procedimento que oferece aos estudantes um caminho autônomo e crítico acerca das múltiplas 
leituras, pode motivá-los de maneira mais legítima a descobrirem suas próprias concepções sobre textos e, por extensão, sobre a realidade.

O letramento literário, como prática social, tem relação com as leituras realizadas pelo indivíduo, na escola ou fora dela, e que se constituem um exercício através do qual é desenvolvido o gosto pelo ato de ler, o que propicia a autonomia individual na seleção de textos e ampliação de horizontes de leitura. E, além disso, o letramento literário promove a tomada de consciência a partir da atividade leitora, sobre os textos e também sobre os sentidos que projetam ou que recebem da realidade circundante (COSSON, 2014). E uma condição fundamental para que esse letramento ocorra é a apropriação do texto literário por parte do leitor, de forma que não se limite aos aspectos e sentidos mais superficiais, tendo a condição de perscrutar suas relações com outros textos e ideias (LAJOLO, 2002; PAULINO, 2001).

Diante do exposto, é possível depreender que o letramento literário, em sua proposta emancipatória, está relacionado com o princípio da motivação intrínseca, pois se conecta ao fato de que mobiliza os interesses pessoais dos estudantes, suas expectativas, gostos e opiniões, estando menos susceptível às influências externas associadas, por exemplo, aos resultados de atividades escolares específicas. Através dessa modalidade de letramento, é possível incutir nos estudantes uma motivação constante para a leitura, utilizando atividades com textos literários como ponto de partida para as suas múltiplas possibilidades, com orientações dos docentes, mas sem cerceamentos quanto aos caminhos associativos que podem ser desenvolvidos pelos estudantes entre os textos e as suas referências socioculturais. Isso porque, para Cosson e Souza (2011), o principal objetivo do letramento literário na escola é formar leitores capazes de alcançar inserção social e de manipular seus instrumentos sociais e, a partir deles, constituir um sentido para si e para o mundo em que vivem. A formação do leitor crítico, consciente e, acima de tudo, letrado literariamente representa o resultado de condutas motivadas do ato de ler e refletir, não só sobre o texto literário, mas sobre a própria condição de estar no mundo.

\section{CONSIDERAÇÕES FINAIS}

O desenvolvimento da leitura pode proporcionar ao estudante o desvelar de uma nova vida em sociedade, não só pelo contexto profissional, mas principalmente em se considerando o aspecto transformador da leitura, desde que seja concebida como atividade autônoma, reflexiva e crítica. Portanto, o estudante precisa ser dotado de mais protagonismo no processo de ensino da leitura, para que, em associação com a sistematização e organização da escola, o profissionalismo do professor e o apoio de textos e livros, consiga alcançar o desejado objetivo de se tornar um leitor crítico, capaz não apenas de decodificar os sinais que lê, mas capaz de ler, interpretar, refletir sobre o mundo que o cerca e, a partir disso, ser capaz de discutir, propor e trilhar caminhos para o desenvolvimento da vida em sociedade. Assim, cabe refletir sobre os elementos que compõem a relação entre leitura e escola, valorizando esta como espaço natural do contato do discente com a leitura, sem desprezar seus referenciais pessoais e familiares. $\mathrm{Na}$ escola, a relação do estudante com o ato de ler deve levar em consideração, ainda, o papel do professor como mediador de leituras e como alguém que seleciona e utiliza textos com o escopo de proporcionar aos discentes um acesso mais democrático, crítico e agradável ao mundo da leitura.

O ensino de literatura, por sua vez, pode se constituir como elemento motivador para a formação de leitores na escola, desde que sejam levadas em consideração a opinião de estudantes e suas referências pessoais na escolha dos textos, preservando, em contrapartida a autonomia do professor, que deve ser o condutor que propiciará a descoberta de novas possibilidades de leitura literária. Nesse sentido, é possível que o letramento literário seja um caminho eficiente para 
proporcionar não só o interesse pela leitura, mas acima de tudo a emancipação leitora, capaz de formar o gosto e também a iniciativa de escolha de novas e variadas leituras.

\section{REFERÊNCIAS}

AMADO, I.; SARDINHA, M. G. Ler, um ato com sentido... Reflexões sobre a importância da leitura em sala de aula. In: SARDINHA, M. G.; AZEVEDO, F. (Orgs.). Didática \& Práticas: A Língua e a Educação Literária. Guimarães: Opera Omnia, 2013. p. 33-64.

ANTUNES, I. Aula de português: encontro \& interação. São Paulo: Parábola Editorial, 2013.

AZEVEDO, F. Clássicos da Literatura Infantil e Juvenile Educação Literária. Guimarães: Opera Omnia, 2013.

BERENBLUM, A. Por uma política de formação de leitores. Brasília: Ministério da Educação, 2009.

CAFIERO, D. Leitura como processo: caderno do professor. Belo Horizonte: Ceale/FaE/UFMG, 2005.

COSSON, R.; SOUZA, R. Letramento literário: uma proposta para a sala de aula. (2011). Disponível em: http://www.acervodigital.unesp.br/bitstream/123456789/40143/1/ 01d16t08.pdf. Acesso em 07 de maio de 2016.

COSSON, R. A seleção de textos literários em três modos de ler. In: MACHADO, M. Z.; PAIVA, A.; MARTINS, A.; PAULINO, G. (Orgs.). Escolhas (literárias) em jogo. Belo Horizonte: Ceale/Autêntica, 2009. p. 35-48.

COSSON, R. Letramento literário: teoria e prática. 2. ed. São Paulo: Contexto, 2014.

COSTA, M. C. A Literatura no Ensino Secundário: do que se ensina ao que se avalia. Uma análise das provas de exame do $12^{\circ}$ ano. 2012. Dissertação (Mestrado em Ciências da Educação). Universidade do Minho, Braga, Portugal, 2012.

COUTINHO, F.; AZEVEDO, F. A importância do ensino básico na criação de hábitos de leitura: O papel da escola. In: AZEVEDO, F. (Coord.). Formar Leitores: Das teorias às práticas. Lisboa: Lidel, 2007. p. 35-44.

DIONISIO, M. L. A Construção Escolar de Comunidade de Leitores - Leituras do Manual de Português. Coimbra: Almedina, 2000.

DIONISIO, M. L. Facetas da literacia: processos da construção do sujeito letrado. Educação em Revista, Belo Horizonte, n. 44, p. 41-67, Dez. 2006. Disponível em http:/ / www.scielo.br/scielo.php?script=sci_arttext\&pid=S0102-46982006000200003\&lng=en\& $\mathrm{n} \mathrm{rm}=$ iso. Acesso em 25 Nov. 2017. http://dx.doi.org/10.1590/S0102-46982006000200003. 
FITA, E. C. A motivação. In: TAPIA, J. A.; FITA, E. C. A motivação em sala de aula: o que é, como se faz. 11. ed. São Paulo: Edições Loyola, 2015. p. 77-84.

GERALDI, J. W. Prática da leitura na escola. In: GERALDI, J. W. (Org.). O texto na sala de aula. 3. ed. São Paulo: Ática, 2003. p. 88-103.

GIASSON, J. A compreensão na leitura. Porto: Edições ASA, 1993.

GRAÇA, M. M. Contributos para a reflexão: A formação de leitores literários em contexto escolar. 2009. Dissertação (Mestrado em Ciências da Educação). Universidade de Lisboa, Lisboa, Portugal, 2009.

GUIMARÃES, S.; BORUCHOVITCH, E. O estilo motivacional do professor e a motivação intrínseca dos estudantes: uma perspectiva da Teoria da Autodeterminação. Psicologia: Reflexão e Crítica, Porto Alegre, v. 17, n. 2, p. 143-150, 2004. Disponível em $<$ http:/ /www.scielo.br/scielo.php?script=sci_arttext\&pid=S0102-79722004000200002\&lng=en \&nrm=iso $>$. Acesso em 25 Nov. 2017. http://dx.doi.org/10.1590/S010279722004000200002 .

KLEIMAN, A. Oficina de leitura: teoria e prática. 12. ed. Campinas: Pontes, 2008.

LAJOLO, M. Do mundo da leitura para a leitura do mundo. São Paulo: Ática, 2002.

MARTINS, M. H. O que é leitura. 19. ed. São Paulo: Brasiliense, 2010.

NEVES, E.; BORUCHOVITCH, E. A motivação de alunos no contexto da progressão continuada. Psicologia: Teoria e Pesquisa, Brasília, v. 20, n. 1, p. 77-85, Abr. 2004. Disponível em $<$ http:/ /www.scielo.br/scielo.php?script=sci_arttext\&pid=S0102-37722004000100010\&lng=en $\& n r m=$ iso $>$. Acesso em 26 Nov. 2017. http://dx.doi.org/10.1590/S0102-37722004000100010.

OLIVEIRA, L. Coisas que todo professor de português precisa saber: a teoria na prática. São Paulo: Parábola Editorial, 2010.

PAULINO, G. Letramento literário: por vielas e alamedas. Revista da FACED, Salvador, n. 5, p. 117-125, 2001.

RIBEIRO, F. Motivação e aprendizagem em contexto escolar. Profforma, Portalegre-Portugal, n. 3, p. 1-5, jun. 2011.

ROSÁRIO, P. Motivação e aprendizagem: uma rota de leitura. In: TAVEIRA, M. (Coord.). Psicologia escolar: uma proposta científico-pedagógica. Coimbra: Quarteto, 2005. p. 23-60.

SILVA, E. T. Elementos de pedagogia da leitura. 3. ed. São Paulo: Martins Fontes, 2005.

SILVA, L. “Às vezes ela mandava ler dois ou três livros por ano”. In: GERALDI, J. W. (Org.). O texto na sala de aula. 3. ed. São Paulo: Ática, 2003. p. 82-87. 
SOUSA, M. L. D. Agora não posso, estou a ler! In: CASTRO, R. V. \& SOUSA, M. L. D. Entre linhas paralelas: estudos sobre o português nas escolas. Braga: Angelus Novus, 1998. p. 55-70.

TAPIA, J. A. (2015). Variáveis de interesse e motivação. In: TAPIA, J. A.; FITA, E. C. A motivação em sala de aula: o que é, como se faz. 11. ed. São Paulo: Edições Loyola, 2015. p. 13-16.

YUNES, E. Leitura como experiência. In: YUNES, E.; OSWALD, M. L. (Orgs.). A experiência da leitura. São Paulo: Edições Loyola, 2003. p. 7-16. 